\title{
Chapter 16 \\ Sync That Tune! The Role of Collective \\ Management of Rights in Film \\ Production and Distribution
}

\author{
Rudolf Leška
}

\subsection{Introduction}

In many countries, the practice of collective bargaining between authors and users is older than copyright. The modern predecessor of collective management organizations (CMOs) was a group of dramatic authors led by Beaumarchais and informally organized in 1777 which "unionized" in 1791 under the name Bureau de législation dramatique - following the enactment of the first French Copyright Act of 1791 (Nérisson 2015: 176-177).

Nevertheless, outside France copyright was managed for a long time mostly individually until the late nineteenth century. In simple one-to-one relationships between authors and their publishers, it was an easy undertaking. Publishers initially did not have to engage in licensing of the works to other parties as they were mostly using them by themselves. This changed once the exclusive right of the author to the public performance of the work was recognized. In France, this happened in the landmark case of Bourget v. Morel (Cour d'Appel de Paris, 1849) (Albinsson 2014); in the Habsburg monarchy, this was enacted for the first time in $1841 .^{1}$ While licensing drama or opera for theatrical performances (so-called grand rights) might not be difficult due to the limited number of performed works, licensing the right of public performance to variety establishments, dance halls, restaurants, etc. (so-called small rights or petits droits) poses challenges to the licensing process. Users need a blanket license to a significant amount of musical works to amuse their clients. In copyright jargon and in this study, the term user means a person who communicates the work to the public or who is otherwise engaged in dissemination or multiplication of the work; that is, who uses the work. Note that from this perspective, a person who

\footnotetext{
${ }^{1}$ Kanzleidekret vom 15. Mai 1841 [Decree of the Chancery dated May 15, 1841] Nr. 537 J.G.S. [Justizgesetzsammlung].

R. Leška ( $\bowtie)$

University of Finance and Administration, Estonská 500, 10100 Prague, Czech Republic e-mail: leska@mail.vsfs.cz 
simply consumes the work by watching it, reading it, listening to it or purchasing a copy of it is not considered a user.

Historically, musical authors (lyricists and composers) and their publishers joined their efforts to get paid a royalty for public performances and established the first $\mathrm{CMO}$ in the field of music rights-SACEM ${ }^{2}$ - to protect their collective interests and engage in collective bargaining (Nérisson 2015: 177). This organization continues to operate to this day as the world's biggest CMO. Importantly, it also enabled the users to get a license easily and allowed for effective joint administration of copyright in a vast quantity of works. In other words, it helped to reduce transaction costs (Albinsson 2012).

Composers and lyricists have been successful in pursuing collective management of their rights in nearly every area of licensing (except for the printing and distribution of sheet music which remained the exclusive territory of publishing houses). Other authors and performing artists ${ }^{3}$ are (generally speaking) collectively represented only for uses where the nature of such use does not allow for individual negotiation of a license at all (such as retransmission by other organizations than the original broadcaster, certain public performances, such as in hotels, restaurants and similar establishments, collection of just remuneration for private copying, etc.).

This development is analogous to the unionization of workers. But no matter how important this achievement was, it also created challenges for today's film distribution. A film producer usually clears all rights and retains exclusive licenses or is assigned the copyright to the film itself, as well as to all works and performances synchronized with the picture of the film (utilized in the film). This, however, is not the case for music. Long-established licensing practices of the music industry generally do not allow the film producer a one-time "buy out" of the copyright for music and the underlying sound recording, ${ }^{4}$ including the rights of performing artists whose performances are embodied in the recording.

In this study, we will examine how collective management works in film, or, more broadly, in audiovisual production and distribution, and analyze the ability of collective management in music to respond to the demand for innovative film distribution and transaction costs related to music licensing.

\footnotetext{
${ }^{2}$ Société des auteurs, compositeurs et éditeurs de musique.

${ }^{3}$ The rights of performing artists, even if recognized in the case law of various countries since the early twentieth century, were not collectively administered in Europe until the second half of the last century. Cf. Leška (2019b).

${ }^{4}$ I am using the technical term phonogram and the US term sound recording, considered informal in the European milieu, interchangeably.
} 


\subsection{Peculiarities of Traditional Music Licensing in Audiovisual Production and Distribution}

Music has always been crucial for filmmakers. Already in the silent era, films were designed to be performed with music and music has remained an essential element for cinematographic enjoyment (Cohen 2011). Thus, if a producer decides to make a film, having to deal with music is inevitable. It is a matter of course that a film cannot be used without the proper authorization to use the music involved, unless the musical material is from the public domain. ${ }^{5}$

As mentioned, while a film producer usually holds a bundle of rights in and to the film (and protected subject matter included in the film), music is an exception. Technically speaking, the music itself consists of the following three components:

- Underlying composition and, if any, text (lyrics, libretto, etc.);

- The artistic performance by performing artists (musicians, singers, narrators, conductor, choirmaster, as the case may be);

- The phonogram (sound recording).

At the moment of production, depending on the jurisdiction where protection is sought ${ }^{6}$ some or all of the following rights might be affected:

- The economic (property) right of reproduction (the protected subject matter needs to be copied to be included in the film, including copies made in the course of production) - in the licensing practice, this and synchronization are together referred to as "mechanical rights";

- The right of synchronization, i.e., synchronization of music to a motion picture ${ }^{7}$;

- Moral rights of authors;

- Moral rights of performers.

Once the film is produced, the subsequent distribution usually affects all other property rights: reproduction or mechanical rights when copies of the film are made and "performance rights," known in the World Intellectual Property Organization (WIPO) and EU documents as "communication to the public." Moral rights might be also affected depending on how the distribution is done-e.g., an interruption of the broadcast by advertising might be considered harmful to the reputation of the author,

\footnotetext{
${ }^{5}$ And, as will be noted, on the global market even the simple question whether a musical work or a sound recording belongs to the public domain is often difficult to answer.

${ }^{6}$ In intellectual property law, the conflict-of-laws principle of lex loci protectionis finds its application in most national laws. In fact, I am not aware of any jurisdiction which would not follow this principle. This means that the laws of the country where IP protection is claimed by the rightsholder apply and that the claim is assessed under these laws. While this usually does not cause any problems in offline use, global online use brings new challenges to this traditional legal principle, as will be shown below.

${ }^{7}$ The right of synchronization (i.e., the act of incorporating music into a film) is not recognized on the international level by any of the copyright-related agreements, but it nevertheless is written into the national laws of most developed nations, sometimes only through case law, such as in the USA. Cf. 1 Melville B. Nimmer, David Nimmer, Nimmer on Copyright § 2.09[A] (2007).
} 
touching upon his moral right of integrity (again, depending on the jurisdiction). As all of the above-mentioned rights are cleared differently, the case is already quite complex in an offline world even without digital distribution which brings additional challenges.

\subsubsection{Licensing Author's Rights}

Since the licensing of the author's rights (copyright) of the composer and lyricist has a long tradition - as old as cinema itself - the licensing situation is relatively more straightforward than with the other rights that we will deal with later.

Rights in the composition (so-called "music publishing rights") include mechanical and performance rights. The film producer usually deals only with certain mechanical rights while the performance rights are cleared through a performance rights organization (PRO). Performance rights organization is a collective management organization in charge of licensing performance rights. ${ }^{8}$

\subsubsection{Mechanical Rights (Right of Reproduction and Synchronization)}

If making copies of a film is necessary, the user of the film needs to deal with mechanical rights. This covers not only DVD distribution, but also situations in which copies are made for the broadcasting of the film by the broadcaster or the online offer of the film on a VOD platform - the user may clear these rights through a mechanical rights organization.

As the nature of mechanical rights dictates, these are only cleared in the country where the copy is made. During the production, this is usually the country of the producer's domicile where the film production takes place, or, to be very specific, where the post-production is done because it is usually in the course of post-production when music is copied and synchronized with the picture.

There are generally several possible licensing scenarios, depending on whether or not the author is represented by a CMO and whether the author has a deal with a music publisher. Since almost all authors of music and text and their publishers are represented by a CMO, most of the rights are licensed through a CMO. Although the rightsholders are usually represented by a CMO only in their home country, the global network of reciprocal agreements of authors' societies associated within CISAC $^{9}$ allows any other sister organization to license these rights on behalf of foreign authors. If an author or his publisher (to whom distribution rights were

\footnotetext{
${ }^{8}$ In some countries, like the UK and USA, mechanical and performance rights are licensed through different entities or CMOs, while in others, mostly in continental Europe, music CMOs license mechanical as well as performance rights.

${ }^{9} \mathrm{CISAC}$, the International Confederation of Authors and Composers Societies (Confédération Internationale des Sociétés d'Auteurs et Compositeurs), is an international organization associating
} 
Author with publisher

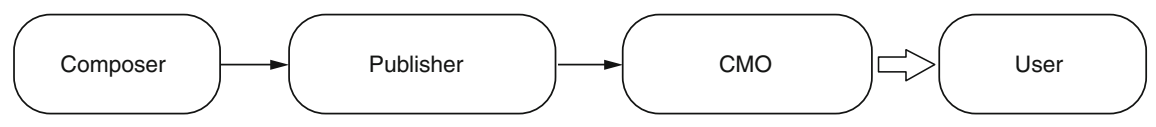

Author without publisher

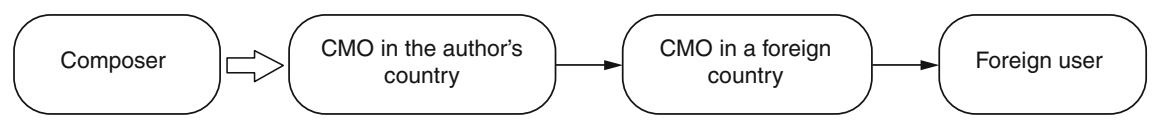

Fig. 16.1 Flow of rights from the author (composer) to the user

assigned or exclusively licensed) is not represented by a CMO, all rights to the composition are licensed by the author/publisher directly to the film producer, not only for the mere production of the film, but also for its distribution. This makes it clear why composers and lyricists (and publishers) prefer to be represented by a CMO - instead of a lump sum payoff for their rights by the producer, they will enjoy recurring royalties from every use of the film which, when aggregated, usually generates far higher income than an upfront lump sum payment ever would. Thus, direct licensing by CMOs to individual users brings to authors more remuneration but also higher transaction costs; on the other hand, the transaction costs are distributed among many players and for individual users are not high, particularly if done by blanket licensing as on the TV market (Fig. 16.1).

Even if there is a CMO representing the rights in the composition, there are traditional exceptions to collective administration of rights, such as the use of sheet music (print rights), theatrical rights known as grand rights (use in live theater) and the synchronization right. While the former two are out of our purview, the latter is important. Unless the rightsholder appoints a CMO to administer the synchronization right, which rarely happens, the producer needs to seek synchronization approval directly from the publisher or, if there is no publisher, the author. This allows the publisher or the author to better monetize the value of the synchronized music in accordance with the nature of the audiovisual work, be it a film or advertisement. Unlike in the case of collective management, the rightsholder is not bound to any published tariff and can negotiate their price freely. In some countries, such as the Czech Republic ${ }^{10}$ and Slovakia (Kabošová 2019), the practice is to license synchronization rights for television broadcasters' in-house productions (for their use) through CMOs. This practice benefits the broadcasters who do not have to worry

authors' CMOs around the world. Importantly, it does not associate CMOs operating in the field of rights related to copyright.

${ }^{10}$ Cf. 2019 tariff for broadcasters and retransmitters published by Collective Rights Management Society for Musical Works (OSA 2019). 
about using popular music in their programs (except for third-party advertisements ${ }^{11}$ where individual granting of rights is still needed).

Practically speaking, the film producer checks with local music CMO to assess which rights the CMO can grant and which must be licensed directly by authors or their publishers, if a publishing agreement is in place. Typically, the film producer concludes — as far as the author's rights are concerned-only a synchronization agreement with the publisher. As mentioned, such an agreement is concluded on individually negotiated terms and not under the tariff published by a CMO.

Importantly, the licensing practice of synchronization licensing has evolved in such a way that the music publisher usually-besides granting the synchronization license-makes the provision of license conditional and prohibits certain forms of distribution of the film. Under these terms, the producer usually agrees - in exchange for lower synchronization remuneration-to not distribute the film in certain territories (such as the USA) or to disallow the exploitation of certain rights (e.g., distribution in cinemas). Depending on the construction of the contract, the producer either has to pay an additional fee (agreed in advance) for broader distribution than initially intended, or to renegotiate additional remuneration under new terms. These contractual conditions go beyond statutory copyright protection because the right to synchronize is legally consumed once the synchronized reproduction is made and this act cannot be repeated, but the law is not settled on this issue. It is disputed whether non-compliance with the synchronization terms constitutes copyright infringement or "merely" a producer's breach of contract. ${ }^{12}$ Exceptionally, the film producer or broadcaster might be forced to change the entire soundtrack due to prohibitively expensive additional synchronization fees associated with extended distribution.

It depends on local practice whether a producer needs to have a mechanical license from a CMO in addition to the synchronization license, or whether this is cleared together with the synchronization right negotiated directly with the publisher.

\subsubsection{Moral Rights}

An intriguing issue relates to the exercise of the moral rights of authors. In certain jurisdictions with the tradition of author's rights (droit d'auteur), strong moral rights give authors the possibility to prevent certain uses which might be derogatory to their work or reputation. Depending on local laws, this can include the right to prevent

\footnotetext{
${ }^{11}$ Other exceptions, such as musical movies, might be applicable as well, depending on the practice of individual CMOs; few of these exceptions are harmonized globally.

${ }^{12}$ In Czechia, the High Court of Prague has ruled that DVD distribution of a film which exceeds contractual conditions agreed between the original producer (Czech Television in this case) and the provider of the synchronization license (OSA, a Czech CMO) infringesthe synchronization right (unpublished decision in the case Radomíra Muchová vs. BONTONFILM a.s., File No. 5Co $15 / 2018$ dated November 21, 2018). In my opinion, the court's interpretation is wrong. The case has not yet been closed, as the High Court remanded the case for a retrial. An extraordinary appeal to the Supreme Court will be possible after the new trial and a likely appeal.
} 
some or any changes ${ }^{13}$ to the work, such as colorization, ${ }^{14}$ or the interruption of the film with commercial breaks. ${ }^{15}$ In some countries, the act of synchronization is considered to be an exercise of moral rights rather than exercise of property rights as its nature lies in connecting a new work (the film) with preexisting musical work which might be ultimately a matter of taste for the composer in deciding how the music is associated with a specific film or scene. ${ }^{16}$

From the user's point of view, the tricky issue with moral rights is that they can only be exercised personally by the author and usually cannot be assigned, licensed or waived; furthermore, in some jurisdictions (e.g., France or Czechia) they are granted for perpetuity (exercised posthumously by the author's spouse or offspring). ${ }^{17}$ But the physical distance between, say, a Slovak commercial broadcaster and a French author's offspring might prove too excessive for the user to seek individual permission for the interrupting of a broadcast by advertisements. In jurisdictions in which synchronization is considered to be a moral right which cannot be licensed, the authors grant in practice power of attorney to the publisher, allowing the publisher to exercise moral rights on the author's behalf. To date, there are no precedents establishing whether or not moral rights can be exercised by an attorney. For the sake of argument, it is assumed here that delegation to an attorney is possible.

It should be noted that the licensing process is substantially the same regardless of whether the producer commissions original music or not. If the author (or publisher) is represented by a CMO, the producer does not clear rights in music distribution with the author; instead, users do so with the respective CMOs (see the chart above). ${ }^{18}$

It is a prevailing worldwide practice that publishers and authors (composers and lyricists) share the proceeds from collective rights management equally-a practice which is usually incorporated in the distribution plans of CMOs. A concentrated

\footnotetext{
${ }^{13}$ For example, Czech law prohibits any changes of the work without the author's consent. The only exception is if a licensee is making minor changes which the author must under the circumstances justifiably bear; the author may even reserve such right in the contract.

${ }^{14} \mathrm{Cf}$. a French case over the broadcast of a colorized version of The Asphalt Jungle: Turner Entertainment Co. v. Huston, CA Versailles, Civ. Ch., No. 68, Roll 615/92 (1994), No. 16; reprinted in English: 10 ENT. L. REP. 3 (1995). Another case comes from Italy: Zinnemann v. TV Internazionale, Trib. Rome 2005 (concerning the colorization of the film The Seventh Cross). French and Italian courts found colorization to infringe the moral rights of the author, even if the user had a license to use the films. A similar outcome can be expected in the case of adapting music to a film without the author's consent.

${ }^{15}$ French and Swedish courts found it infringing to interrupt a broadcast without the author's consent; this agrees with the practice of DILIA, the CMO representing film directors in the Czech Republic. Cf. Paris Court of Appeal, November 26, 1990, Images Juridiques, January 15, 1991; Supreme Court of Sweden [Högsta domstolen], NJA [Nytt Juridiskt Arkiv] 2008, p. 308.

${ }^{16}$ In Czechia, the legal doctrine underwent a major shift from the original approach, in which many scholars considered synchronization right [\$ 62(2) of the Czech Copyright Act] to be a moral right, to the current approach according to which most agree that it is actually a property right.

${ }^{17}$ Moral rights are inheritable, but in many countries they can be exercised — to certain degree—by the author's descendants (not the legal heirs).

${ }^{18}$ In practice, the users sometimes force authors to opt out from collective management and grant the license directly to them.
} 
effort by competition authorities in Europe led to a loosening of this longstanding tradition for the sake of increasing competition, to the detriment of authors.

The practice of CMOs which divide the proceeds between authors and publishers has led some broadcasters to operate as music publishers as well, asking music authors to enter into publishing deals with them when commissioning music for their productions. This new practice, harmful to the standard operation of the system, has in rare exceptions also been adopted by some film producers because it allows them to get a share of the music royalties back from the film distribution if they become represented by a CMO.

\subsubsection{Licensing Rights Related to Copyright (Neighboring Rights)}

By rights related to copyright, or simply "related rights", I mean a variety of rights different from authors' rights but generally based on the same principles (informal protection of certain expressions). The term "related rights" is the preferred language of the international treaties and the WIPO and hence is used in this chapter instead of "neighboring rights". In the Anglo-American context, the term copyright includes both, authors' rights and related rights, which is why I try to avoid this term here in order not to blur the borders between both categories.

Related rights traditionally include the rights of performing artists and phonogram producers, but in many countries, especially in Europe, this umbrella also covers other subject matter (rights of broadcasting organizations ${ }^{19}$ and event organizers, rights in unpublished works where the authors' rights have expired, rights of press publishers, rights of producers of audiovisual recordings, etc.). Their scope, duration and recognition differ significantly from country to country, and international harmonization is less developed than in the case of the author's rights. ${ }^{20}$ Even in the European Union, only certain related rights are harmonized, while the Member States are free to introduce other intellectual property rights.

Considering the situation in EU countries, the use of music in film production always involves a sound recording (phonogram) and musical performances embodied therein. The film producer thus always has two options: either to record the music (soundtrack) by his own means or to obtain the rights to use an existing recording.

\footnotetext{
${ }^{19}$ Obligatory minimum rights for broadcasters in the European Union are guaranteed by the Rental and Lending Directive.

${ }^{20}$ International treaties, such as the Rome Convention, The Agreement on Trade-Related Aspects of Intellectual Property Rights (TRIPS), WPPT and the Beijing Treaty on Audiovisual Performances (BTAP), cover only the rights of performing artists, phonogram producers and broadcasting organizations.
} 


\subsubsection{Film Producer as a Phonogram Owner}

In the first case, the producer contractually clears the rights with performing artists by way of an assignment or license and becomes the owner of the rights of the phonogram ${ }^{21}$ producer (these rights are imprecisely referred to in the licensing jargon as "master rights"). Many film producers also dispose of a significant amount of sound recordings to which they own the phonogram producers' rights, which allows them to be represented by a CMO administering the rights of phonogram producers and to earn profits from the use of the phonogram (including the use of the phonogram in the film).

While the phonogram producer's rights are fully assignable anywhere in the world, this is not always the case with performers' rights. This might make cross-border trade troublesome. Performers' rights in certain European jurisdictions, mostly in central Europe, ${ }^{22}$ are not assignable. Under the long-established principles of copyright territoriality, the individual countries recognize only such agreements which are in accordance with local rules on assignability (even if the contract itself is governed by foreign law). In other words, the assignment of rights, unlike a license, would be most likely unenforceable in jurisdictions that do not allow for such assignment. Foreign assignees (producers) often lack this information and might end up concluding agreements that do not provide them the worldwide rights clearance they might have hoped for. More sophisticated contracts address this issue by combining the assignment with an exclusive license (activated in case the assignment is void or unenforceable).

\subsubsection{Film Producer as a Licensee}

The second option is to acquire an existing license instead of investing in a new recording. Unlike the author's rights ("publishing rights"), these rights are usually not collectively administered. In other words, they are collectively administered only to a more limited extent and are usually cleared individually under negotiated business terms, which mean that the phonogram producer (the record label in this case) clears most of the rights with the performing artists. The label is then able to license the phonogram rights bundled with rights to artistic performances. Therefore, if a film producer seeks authorization to use a phonogram in a film, he or she needs to negotiate only with the record label who grants to the film producer not only the mechanical and synchronization license to use the phonogram with performances for the film production but also a license for the consecutive use of the film with a synchronized phonogram to the extent demanded by the film producer.

\footnotetext{
${ }^{21}$ Legally speaking, a phonogram is immaterial subject matter protected by the law; the term is sometime used interchangeably, but imprecisely, with the US term "sound recording".

${ }^{22}$ For example, Germany, Austria, Czechia and Slovakia.
} 


\subsubsection{Single Equitable Remuneration for Performers and Phonogram Producers}

The collective administration of rights in phonograms and performances typically covers areas with mandatory and extended collective management, such as fair compensation for private copying, rental and lending rights or retransmission of a broadcast. In addition, countries that are signatories to the Rome Convention ${ }^{23}$ or the WIPO Performances and Phonograms Treaty (WPPT) ${ }^{24}$ are required to introduce at least ${ }^{25}$ a system of so-called single equitable remuneration, which some countries rightly made subject to mandatory collective management. The understanding of the meaning of single equitable remuneration among the signatory countries is not entirely settled, but it can be said that "single" does not mean a one-time lump sum payment but rather a payment for every "single" use of the phonogram (Reinbothe and von Lewinski 2015: 396). While in some countries the concept cannot be put into practice outside of the system of (possibly mandatory) collective management, others leave it to collective bargaining between the stakeholders or opt for a grant of exclusive rights to performers and producers. ${ }^{26}$ It is, of course, important for the film producer to understand where the use of the phonogram (with performances) is subject to mandatory collective administration of the remuneration system. ${ }^{27}$ Such rights cannot be cleared individually by the film producer. It will be subject to rights clearance between the user (typically the broadcaster) and the respective CMO administering the rights of phonogram producers and performing artists. The most typical example is the regulation of broadcasting. Many countries have opted for mandatory or extended collective management of commercial recordings used in broadcasting to ease the burden on the broadcaster (both radio and TV broadcasters) who consequently does not have to negotiate individually with record labels ${ }^{28}$ and can clear the rights under a blanket license for a royalty negotiated with the CMO or set by governmental tariff as the case may be.

Needless to say, the whole system of equitable remuneration from TV broadcasting of phonograms synchronized with films is at stake in Europe at the time of going

\footnotetext{
${ }^{23}$ Rome Convention for the Protection of Performers, Producers of Phonograms and Broadcasting Organizations (1961).

${ }^{24}$ WIPO Performances and Phonograms Treaty (1996).

${ }^{25}$ The remuneration right is considered to be a minimal right. Countries are free to adopt stricter protection by granting exclusive rights to producers and performers. Cf. Reinbothe and von Lewinski (2015: 395).

${ }^{26}$ Although exclusive (property) rights are considered a stricter form of protection than remuneration rights, for the performers this might not be true as they are often forced to assign or grant their rights for a lump sum payment without any right to a later royalty from the actual use of their performances (as is the case under the remuneration right scheme).

${ }^{27}$ This is the case in Czechia.

${ }^{28}$ For the system to operate smoothly, it is beneficial if the synchronization right for the broadcaster's own productions is also collectively administered. Where the broadcaster has to negotiate synchronization deals individually (e.g., in the UK or Hungary), the broadcaster's administrative and clearance costs remain high.
} 
to press, with a pending case before the Court of Justice of the European Union. ${ }^{29}$ In that case, the broadcaster argues that once the phonogram is synchronized with the film, it ceases to be a phonogram (it is "amalgamated" to the audiovisual recording) and no equitable remuneration is due from the TV broadcast of such a film. ${ }^{30}$

The system of single equitable remuneration is closely linked to the concept of the phonogram published for commercial purposes ("commercial recording"), which was first introduced by the Rome Convention in 1961. Under the convention, phonograms that are intended for public distribution (published on media available for purchase) are deemed "commercial recordings." The intent of the drafters was clearly not to include recordings made by the broadcasters themselves (if made for their own broadcast and not for public distribution), but many questions remain open. ${ }^{31}$ In any case, the concept was originally meant to serve primarily radio broadcasters who were able to buy phonograms freely available on the market and then use them in their broadcasting under a blanket license without bearing the burden of negotiating an individual broadcasting license, while at the same time the phonogram producers and the artists got a guarantee of remuneration. The purposefully chosen neutral language was from the beginning meant to cover television broadcasting. The emergence of online distribution of music made it one of the key points of the WIPO Internet Treaties. ${ }^{32}$ The WPPT has enlarged the concept to include not only phonograms published on physical media but also phonograms made available to the public online (in such a way that members of the public may access them from a place and at a time individually chosen by them). Under this broad definition, every phonogram-except those produced for internal purposes or the purposes of film, radio and TV production (i.e., not intended for divulgation online or on physical media as a separate soundtrack) — is considered a "commercial recording."33

The WPPT broadened the concept of single equitable remuneration to include not only broadcasting but any communication aimed at the public, which includes the making-available right for on-demand online use. The diverging national laws

\footnotetext{
${ }^{29}$ Pending case C-147/19, Atresmedia Corpración de Medios de Comunicación, S.A. v. AGEDI and AIE.

${ }^{30}$ I find this opinion clearly wrong as it does not respect the traditional rule that more layers of rights can exist next to each other (e.g., audiovisual recording, the film, the rights of performers, the rights of the author of the original novel, etc.), but the outcome at the Court of Justice is uncertain.

${ }^{31}$ For example, whether the commercial recording must be available to consumers or whether availability for purchase in $\mathrm{B} 2 \mathrm{~B}$ relations is sufficient to consider a phonogram to be a "commercial recording".

${ }^{32}$ WCT and WPPT, the outcome of WIPO's 1990s digital agenda, are referred to as the Internet Treaties.

${ }^{33}$ One disputed issue is whether recordings offered by so-called production music libraries should be considered "commercial recordings"; nevertheless, prevailing practice considers them to be commercial recordings as they fulfill the definition, unless such recordings are delivered to the customer in an individual and closed B2B communication, such as via a private FTP server. The advantage of production music libraries for users lies in the fact that the operator of the library bundles together the rights of authors, performers and phonogram producers (publishing and master rights), thereby easing the burden of negotiation for synchronization with the publisher and record label.
} 
bring more uncertainties for the film producer who purchases a license for the use of a phonogram without knowing which rights in which territories are actually covered. Rights under the mandatory collective management or mandatory remuneration scheme cannot be granted by the phonogram producer and are subject to national laws. Thus, it is the ultimate user (typically the broadcaster) who has to pay for the phonogram producer's and performers' rights.

\subsubsection{International Relations in the Field of Related Rights}

The issue of licensing related rights becomes even more intricate once we start examining the international aspects. As mentioned earlier, there is less harmonization at the international level than in the case of the author's rights; many countries, including the EU Member States, adopted modern related rights legislation as late as the 1990s. When the European Community adopted the 1992 Rental and Lending Rights Directive, ${ }^{34}$ only three EC members were granting exclusive rights to performers (as did Czechoslovakia and some other countries) (Leška 2019b). The last twenty or thirty years, during which exclusive rights for phonogram producers and performers have developed (even less in developing countries), were not sufficient for the establishment of a global network of CMOs-today there remain different CMOs in the fields of performers' rights and phonogram producers' rights. In other words, there is a lack of a coherent system of reciprocal agreements, as is the case with authors' rights. Furthermore, as the range of rights is different and the minimal rights guaranteed by the international treaties are narrower (and even these treaties allow signatories to establish significant reservations), ${ }^{35}$ numerous loopholes exist in reciprocal agreements in the field of related rights.

Not only is there an insufficient network of reciprocal agreements, but the protection of phonograms is also not universally accepted and not every country recognizes the rights of foreign phonogram producers or performers unless international treaties require them to do so. The treaties have their own points of attachment. ${ }^{36}$

Signatories to the Rome Convention recognize: (a) the rights to phonograms of nationals from another convention country; or (b) produced in a convention country; or first published ${ }^{37}$ in a convention country. ${ }^{38}$ Importantly, if a phonogram is

\footnotetext{
${ }^{34}$ Council Directive 92/100/EEC of November 19, 1992, on rental right and lending right and on certain rights related to copyright in the field of intellectual property. It was replaced by Directive 2006/115/EC.

${ }^{35}$ The most prominent example is the USA, which grants the right of public communication and broadcasting of phonograms and performances only for digital uses (such as simulcasting and webcasting) and in its national laws excludes traditional broadcasting and communication in business establishments from the rights of phonogram producers and performers.

${ }^{36}$ Articles 4 and 5 of the Rome Convention, Article 3 of WPPT.

${ }^{37}$ The Rome Convention defines publication as the offering of tangible copies of a phonogram to the public.

${ }^{38}$ The contracting party may, however, include a reservation to not apply the criterion of publication or the criterion of fixation to a phonogram. Points of attachment for performers refer to the place
} 
published in a non-convention country, it is protected in the convention countries provided that the simultaneous publication occurs within thirty days. ${ }^{39}$ The USA is not a signatory to the Rome Convention, but this rule allows US record labels to receive protection in Rome Convention countries through simultaneous publication in Europe (typically the UK). ${ }^{40}$

Under the WPPT, signatories are obliged to recognize-with certain explicitly listed exceptions ${ }^{41}$ - the mutual rights of the nationals of another WPPT signatory country who are defined as performers (phonogram producers) and who meet the criteria for eligibility under the Rome Convention.

The consequence for the film producer is that the mere question of whether the phonogram he or she is purchasing for the film is protected in the countries for which he or she acquires the license is a difficult one. ${ }^{42}$ It is not uncommon in practice that the phonogram (performers') rights are cleared for territories or uses for which there is no need to do so, while they are not cleared where necessary, especially in the field of new media (see Sect. 16.3).

\subsection{Licensing Online Film Distribution}

While licensing in the offline realm is certain, or at least fairly predictable, in particular when it comes to licensing music for film distribution with CMOs, the online sphere poses more challenges to traditional licensing schemes. The crucial conflict is between the ubiquitous nature of the World Wide Web and the mandates of CMOs, which remain largely territorial.

\subsubsection{Rights Affected}

Services like video on demand, broadcasters' catch-up services and previews, Internet Protocol Television (IPTV), network personal video recorder (NPVR), time-shifted

\footnotetext{
where the performance takes place or whether the performance is fixed on a phonogram protected under the convention or is part of a broadcast protected under the convention.

${ }^{39}$ Art. 5(2) of the Rome Convention.

${ }^{40}$ Nevertheless, the Rome Convention permits reservations in this regard allowing the signatories not to protect phonograms from non-convention countries which are simultaneously published in the convention country.

${ }^{41}$ That is why other WPPT countries may, but do not have to, provide protection to US phonograms if they are broadcasted in their territory.

${ }^{42}$ As an example: any pre-1972 US recordings, including the oldest historical recordings, might continue to be protected by various US state laws until 2067 (!), while any pre-1963 or pre-1965 recordings are in the public domain in the EU and Canada, respectively.
} 
retransmission, simulcasting, webcasting, etc., all require different licenses or licensing practices. The main difference lies in the legal distinction between three forms of distribution:

- Linear television broadcasting (usually under extended collective management of music and mandatory collective management of commercial recordings);

- Retransmission (usually under mandatory collective management);

- Nonlinear (on-demand) online services (usually under facultative collective management of music and direct licensing of sound recordings).

Once territoriality is factored in, the resulting situation becomes extraordinarily complicated as a separate license is generally required for every territory where the service is available. ${ }^{43}$

Linear television broadcasting, even in the online environment, is licensed in the same way as traditional broadcasting. From the copyright perspective, it is irrelevant whether it takes the form of simulcasting or webcasting. This means that where a country maintains a mandatory scheme of single equitable remuneration for phonograms, it also covers simulcasting and webcasting-but only for the territory of the specific country, forcing broadcasters to implement geoblocking measures. The revised SatCab Directive ${ }^{44}$ tried to alleviate this problem at least within the EU single market, but failed to do so. The directive introduces the legal fiction that the use of a TV program ${ }^{45}$ occurs only in the EU Member State of the broadcaster's principal establishment unless the parties to a license contract otherwise. This covers the simulcasting of programs (but not webcasting) and broadcasters' catch-up services. The directive expects that the parties will agree on appropriate remuneration which takes into account the availability of the service. Even if the CMOs expect each other's sister organizations to charge remuneration equal to a sum of 27 national tariffs, ${ }^{46}$ such pricing would be prohibitive for the provision of such services. As a result, the broadcasting industry itself seems to insist on contractual clauses for mandatory geoblocking in exchange for a lower license fee. Ironically, the broadcasters themselves ask CMOs to include a geoblocking clause in the license agreement to avoid being charged fees for broader territory.

In the field of musical works, simulcasting and broadcasters' catch-up services are expressly excluded from multi-territorial licensing under the CRM Directive, ${ }^{47}$

\footnotetext{
${ }^{43}$ According to the Bogsch Theory, which is supported by court decisions. Cf. Ricketson (1987, 442-452).

${ }^{44}$ Directive (EU) 2019/789 of April 17, 2019, laying down rules on the exercise of copyright and related rights applicable to certain online transmissions of broadcasting organisations and retransmissions of television and radio programmes, and amending Council Directive 93/83/EEC. ${ }^{45}$ Only news and current affairs programs and fully financed in-house productions of the broadcasting organization (except sports events).

${ }^{46}$ It is unclear how these proceeds should be distributed among rightsholders. Is the licensing CMO obliged to distribute the proceeds to rightsholders abroad if - legally speaking — the use occurred only in the Member State where the CMO is established?

${ }^{47}$ Art. 32 of the Directive 2014/26/EU of February 26, 2014, on collective management of copyright and related rights and multi-territorial licensing of rights in musical works for online use in
} 
and broadcasters must rely on the minimal rights provided by the SatCab Directive. If a broadcaster wishes to simulcast other programs or to simulcast globally (outside of the EU) without geoblocking, infringement in at least some territories is nearly unavoidable.

Retransmission taking place in a managed environment online (IPTV) is usually licensed under a mandatory collective management scheme, ${ }^{48}$ which means that the rights cannot be licensed individually. However, if a producer enters into a contract licensing certain retransmission rights, such a contract would be unenforceable in most European jurisdictions because, under mandatory collective management, the rightsholder cannot dispose of the rights by himself.

Nonlinear (on-demand) online services are licensed in the field of music under facultative collective management (i.e., only on behalf of contractually represented authors) while in the field of phonograms (and performances embodied therein) such services are usually licensed directly by record labels, but exceptions exist. ${ }^{49}$ Again, the problem with territoriality remains, because generally, the use takes place in every country where the service is available,${ }^{50}$ which means the user either seeks a multi-territorial license or adopts geoblocking technology. A user who does neither may be liable for copyright infringement.

Unfortunately for lawyers, the services are often combined. Consider a retransmission service such as Skylink. The linear retransmission must be licensed through a mandatory collective management scheme in every country where the service is available, while the ancillary nonlinear services for customers, such as NPVR or timeshifted retransmission (meaning the customer can rewind the retransmitted program), must be licensed directly with the film producers and record labels. ${ }^{51}$ No wonder that such licenses are often missing and the users infringe the rights and risk litigation (or even criminal liability) to avoid complicated negotiation with rightsholders. A similar decision-making matrix applies to Hybrid Broadcast Broadband (HbbTV) services combining linear and nonlinear delivery of works.

\subsubsection{Global Licensing Arrangements}

The rightsholders are well aware of the difficulty of licensing music for online use, and since the $1990 \mathrm{~s}$, there have been various private initiatives trying to tackle the

the internal market. It is not clear why the directive regulated only authors' rights and not also phonograms when it comes to multi-territorial licensing.

${ }^{48}$ In the EU, such a scheme is for good reasons imposed by Art. 4 of the revised SatCab Directive. ${ }^{49}$ A typical exception is the licensing of catch-up and preview services to broadcasters through CMOs.

${ }^{50}$ One minor exception for the subscription services arises out of the Portability Regulation, Regulation (EU) 2017/1128 of June 14, 2017, on cross-border portability of online content services in the internal market. This exception applies to simulcasting as well, if the service is portable.

${ }^{51}$ In the case of music, the broad mandate of the music CMOs allows them to license music for such ancillary services without any additional burden. 
problem. ${ }^{52}$ The Santiago Agreement ${ }^{53}$ of 2000, an ambitious multi-territorial licensing framework for a global license (also used for music in films) initiated by the International Confederation of Authors and Composers Societies (CISAC) and based on the existing system of reciprocal agreements, failed due to a political decision of the EU Commissioner Prodi that pushed CISAC to abandon the multi-territorial license system (the Commission considered this a restraint of trade in breach of competition rules due to the obligation to license through a CMO established in the country of the licensee's residence).

The International Federation of the Phonographic Industry (IFPI) ${ }^{54}$ developed a similar system for licensing simulcasting, webcasting and on-demand offerings of audio and audiovisual programs, but its practical utilization remains limited due to the lack of an analogous system for licensing artistic performances (without rights in which the phonogram itself cannot be used).

This has led to the development of new business models of supranational licensing hubs often owned by CMOs and rightsholders alike, such as SOLAR, ${ }^{55}$ PEDL, ${ }^{56}$ ICE ${ }^{57}$ Mint Digital Services ${ }^{58}$ and ARMONIA, ${ }^{59}$ not always offering favorable terms to small users or authors. The outcome is the undesirable fragmentation of the license. While it was previously fragmented by territory, now it is fragmented by repertoire (whereby different publishers license through different entities which then provide pan-European licenses). Although these licensing hubs were originally designed for music services, some of them have been involved in licensing music for VOD services. Thus, platforms in Europe must deal with an increasing number of rightsholders and CMOs to get the license for their VOD services unless the platform wishes to stick to the repertoire of one or a few music publishers (which for films is not possible as the used film music is out of the platform's control).

Thus, the licensing of music and phonograms, in particular in the online arena, is now connected with higher transaction costs than before. The EU Commission, which did not allow private schemes to develop, is now trying to solve this problem through regulations such as the revised SatCab Directive and the CRM Directive but so far without any visible success.

\footnotetext{
${ }^{52}$ I have analyzed the historical development of and current situation in global licensing deals and licensing hubs in the field of music in Leška (2019a).

${ }^{53}$ Reprinted in Spada (2006).

${ }^{54}$ The International Federation of the Phonographic Industry is an association of major record labels; in many countries, local IFPI chapters act as CMOs in the field of phonogram producers' rights.

${ }^{55}$ Run by SOLAR Music Rights Management Ltd., cf. www.celas.eu.

${ }^{56}$ Pan-European Digital Licensing.

${ }^{57}$ A joint venture between PRS for Music (UK), STIM (Sweden) and GEMA (Germany).

${ }^{58}$ A joint venture between SESAC (USA) and SUISA (Switzerland).

${ }^{59}$ Associating AKM (Austria), SPAUTORES (Portugal), SUISA (Switzerland), SABAM (Belgium), ARTISJUS (Hungary), SACEM (France), SACEM (Luxembourg), SIAE (Italy) and SGAE (Spain).
} 


\subsection{The Ultimate Task: Simplifying Rights Clearance, Standardizing the Procedures}

It is broadly acknowledged in the industry that it is almost impossible to clear all rights in the course of the production of a film. Not only must users deal with CMOs to get their mechanical or performing licenses to use the music, but the varied practices in the licensing of related (neighboring) rights and the fact that moral rights differ substantially from one jurisdiction to another cause some legal uncertainty-even in the offline world. Once we add the layer of global online use, the situation becomes a nearly impenetrable thicket of rights and rightsholders.

What has been achieved in the field of "offline" authors' rights over a period of decades - a settled and largely standardized way of licensing — needs to be achieved also in the field of related rights, in particular in the online arena. This needs to be done quickly, as much time has been lost in Europe due to questionable steps taken by the European Commission. There are contractual solutions that can be used, but they need the rather radical and proactive involvement of global organizations such as CISAC, SCAPR, ${ }^{60}$ IFPI, PMA ${ }^{61}$ and WIN,${ }^{62}$ who must work together on viable and efficient solutions to set an industry standard for easy and comprehensive licensing and reciprocal agreements.

The problem of complicated rights clearance of music and sound recordings is particularly pressing in the fragmented small European markets, each of which has its own established practices and where the costs of legal advice and know-how might exceed proceeds from distribution.

Yet, we must differentiate between situations where the complicated procedure of rights clearance is caused by flawed laws and where it is an expression of different cultural practices around the globe. The cultural autonomy of nations, big or small, requires that no global practice be imposed upon them without regard for their own traditions-for instance in their attitude toward the moral rights of authors and performers. ${ }^{63}$

\section{References}

Albinsson, S. (2012). The advent of performing rights in Europe. Music and Politics, 6(2), 1-22. Albinsson, S. (2014). A costly glass of water: The Bourget v. Morel case in Parisian Courts 18471849. Swedish Journal of Music Research, 96(2), 59-70.

\footnotetext{
${ }^{60}$ The Societies' Council for the Collective Management of Performers' Rights associates national CMOs in the field of performers' rights.

${ }^{61}$ The Production Music Association associates production music libraries.

${ }^{62}$ The Worldwide Independent Network associates national independent record labels' associations.

${ }^{63}$ This paper was written as part of the junior project "Transformations of Individual and Collective Copyright Management" made possible by institutional support for long-term conceptual development of research at the University of Finance and Administration.
} 
Cohen, A. J. (2011). Music as a source of emotion in film. In P. N. Juslin \& J. Sloboda (Eds.), Handbook of music and emotion: Theory, research, applications (pp. 249-272). Oxford: Oxford University Press.

Kabošová, S. M. (2019). Úskalia synchronizácie. Filmová hudba. https://www.filmovahudba.eu/? page=abeceda-producenta/uskalia-syn\&lng=sk. Accessed August 18, 2019.

Leška, R. (2019a). Globalization of collective rights management and the role of National CMOs. In T. E. Synodinou (Ed.), Pluralism or universalism in international copyright law (pp. 95-114). Alphen aan den Rijn: Kluwer Law International.

Leška, R. (2019b). Performers' rights: A Central European export. In M. T. Sundara Rajan (Ed.), Cambridge handbook of intellectual property in central and Eastern Europe (pp. 222-237). Cambridge: Cambridge University Press.

Nérisson, S. (2015). Collective management of copyright in France. In D. Gervais (Ed.), Collective management of copyright and related rights (pp. 175-204). Alphen aan den Rijn: Kluwer Law International.

OSA. (2019). Sazebník autorských odm en za vysílání a p̌renos vysílání 2019https://www.osa.cz/ storage/DownloadTranslation/1-2000/18-attachment-Sazebnik-OSA-Vysilani-a-prenos-2019. pdf. Accessed August 18, 2019.

Reinbothe, J., \& von Lewinski, S. (2015). The WIPO treaties on copyright: A commentary on the WCT, the WPPT, and the BTAP. Oxford: Oxford University Press.

Ricketson, S. (1987). The Berne convention for the protection of literary and artistic works: 18861986. London: Wolters Kluwer.

Schwemer, S. F. (2019). Licensing and access to content in the European Union. Cambridge: Cambridge University Press.

Spada, P. (Eds.). (2006). Gestione collettiva dell'offerta e della domanda di prodotti culturali . Milano: Giuffrè.

Rudolf Leška is active as Attorney-Partner at the copyright boutique firm Štaidl Leška Advokáti, licensed in Czechia and Slovakia and representing the entertainment industry and advising other private clients and the public sector with media- and copyright-related transactions and litigation. Dr. Leška serves as current President of ALAI Czech Republic and is Senior Assistant Professor in media and copyright law at the University of Finance and Administration in Prague with academic research focused on theater law, collective management, moral rights and the rights of performing artists. He is an associated research fellow at the Palacký University Olomouc in the arts and creative industries research projects.

Open Access This chapter is licensed under the terms of the Creative Commons Attribution 4.0 International License (http://creativecommons.org/licenses/by/4.0/), which permits use, sharing, adaptation, distribution and reproduction in any medium or format, as long as you give appropriate credit to the original author(s) and the source, provide a link to the Creative Commons license and indicate if changes were made.

The images or other third party material in this chapter are included in the chapter's Creative Commons license, unless indicated otherwise in a credit line to the material. If material is not included in the chapter's Creative Commons license and your intended use is not permitted by statutory regulation or exceeds the permitted use, you will need to obtain permission directly from the copyright holder.

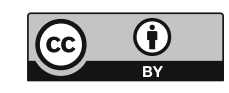

